\title{
Analysis of Buffer Zones of Limestone Mines Areas using Digital Image Processing Techniques
}

\author{
K.S. Siva Subramanian, Abhishek Kumar Tripathi, Ramesh Kant
}

\begin{abstract}
The economic growth of any country crucially depends on the mining activity of that country. The mining activities require huge land for the extraction of mineral from the earth. The recent government policy imposing the systematic mapping of the land use and land cover in and around the mines. In the present study, work, the analysis of land used and land covered was carried out at Malkapur limestone mines. This study discussed the brief mapping of the buffer zones buffer zones areas in by using digital image processing techniques. This research work demonstrated the changes happened in and around mines for the buffer radius of $1 \mathrm{~km}, 5 \mathrm{~km}$ and $10 \mathrm{~km}$. In this study it was found that there were no significant changes observed in land use which intern implies that mining activities are not having any impact in land use changes. Further, in this study, not much variation was reported against the forest land and water bodies situated in and around the mines.
\end{abstract}

Keywords : Digital image processing, mines, buffer zones, Peak vector sum.

\section{INTRODUCTION}

Mining is one of the industrial activities which requires large land to be cleared so that the under-earth minerals can be mined efficiently. Mining operations, such as strip mining, usages of heavy earth moving machine, blasting etc., releases gasses and dust into the air. Also, the implementation of heavy machines into the land remove the top soil which leads to soil erosion and destruction of agriculture land [1]. These phenomena cause the land degradation in and around the mines. Due to these reasons, the deforestation, air pollution and land degradation are the most important problem in any mining activities. Therefore, in order to prevent the land and society around the mining industry the concept of buffer zones is introduced [2].

The buffer zones are defined as the sufficient in size to prevent the introduction of prohibited substance to adjacent land areas. The delineation of buffer zones in mining activities could help in protecting the health and well-being of the local societies and stockholders.

Manuscript received on March 15, 2020.

Revised Manuscript received on March 24, 2020.

Manuscript published on March 30, 2020.

* Correspondence Author

Abhishek Kumar Tripathi*, Mining Engineering, Aditya Engineering College, Surampaelm, Kakinda, Andhra Pradesh, India. Email: abhinitrkl12@gmail.com

K.S. Siva Subramanian, Mining Engineering, AMET University, Chennai, India. Email: hod mining@ametuniv.ac.in

Ramesh Kant, Mining Engineering, AMET University, Chennai, India. Email: rameshkant2010@gmail.com

(C) The Authors. Published by Blue Eyes Intelligence Engineering and Sciences Publication (BEIESP). This is an open access article under the CC BY-NC-ND license (http://creativecommons.org/licenses/by-nc-nd/4.0/)
Also, as per the recent guidelines of Ministry of Environment and Forest Government of India the mapping of every mines which are covering the radial distance of 1 $\mathrm{km}, 5 \mathrm{~km}$ and $10 \mathrm{~km}$ is

mandatory. The analysis of buffer zone can be made by using the digital processing method of remote sensing technique. Remote sensing is an art of the technology which is capable of providing the detailed information about the land (object) without any physical contact with that land.

Now a days, the remote sensing technology is becoming a vital tool in mapping the large surface areas. In this technique, the data interpretation of the reflected energy from the earth surface is recorded which helps in analyzing the surface topography of that earth surface [3]. The very basic advantages of this method are that it can map the large earth surface areas. The data collected in this technique is mainly in three forms, namely, variation in acoustic wave distribution (sonar), variation in force distribution (gravity meter) and the variation in electromagnetic energy distribution (eye) [4]. These remotely gathered information through different sensors might be examined to acquire data about the items or highlights under investigation [5]. Thus, it can be defined as the process of extracting the information of the earth surface parameters using the electromagnetic radiation (EMR) of the earth surface. These electromagnetic radiation wave may be reflected or emitted from the earth surface. Whenever the electromagnetic radiation reaches to the earth surface then three energy interaction may possible such as reflection, absorption and transmission [6]. In the reflection energy interaction, the radiation is bounces off the target and is redirected by the target surface whereas the radiation is absorbed by the target surface in absorption energy interaction. Similarly, the transmission energy interaction is only possible when the radiation passes through the target surface [7]. The procedure of remote sensing can be delegated passive and active remote detecting. The passive remote sensing using sun as the source of energy and the reading solar radiations reflected from the surface are recorded for further analysis. On the other hand, in active remote sensing a kind of energy generated and sent this energy to the target surface in a manner so that the energy reflected from the surface can be recorded for further data analysis [8]. These type of remote sensing techniques is illustrated in Figure 1. 


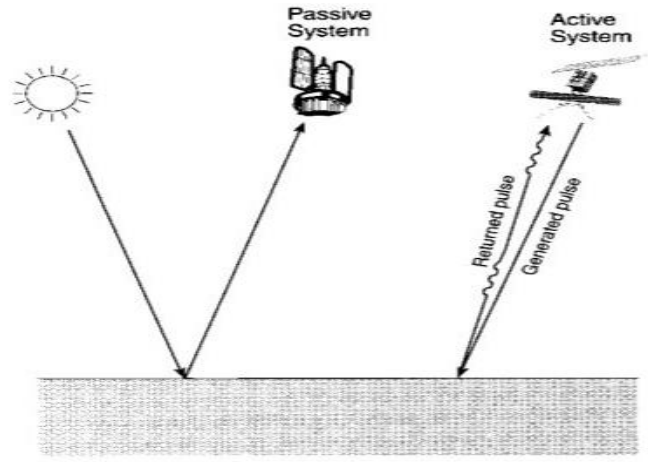

Fig.1. Schematic representation of passive and active remote sensing technique [9]

Since, the new government policies imposes a very strict rules in mapping the lease mining areas and a systematic plan view is Mandatory to full fill the rules and regulation framed by the government. In order to locate the buffer zones around considered limestone mines and provide a complete mapping information the digital processing by remote sensing techniques was adopted [10]. The complete paper consists the five sections where section I discuss the introduction of the present work and section II gives a brief glance of selected mines. The section III of this paper represents the methodology which is adopted for the preparation of land use and land cover. Section IV discuss the results and analysis of the paper which is followed by the conclusions of the paper in section $\mathrm{V}$.

\section{GLANCE OF THE SELECTED SITE}

The Malkapur limestone mines was selected for the present research work. These mines having two contiguous mines located near Malkapur village in Tandur Mandal of Vikarabad District, Telangana State, and is situated between $17^{\circ} 19^{\prime} 50.3^{\prime \prime} \mathrm{N}$ and $77^{\circ} 28^{\prime} 02.7^{\prime \prime} \mathrm{E}$ and $17^{\circ} 20^{\prime} 32.0^{\prime \prime} \mathrm{N}$ and $77^{\circ} 28^{\prime} 38.8^{\prime \prime} \mathrm{E}$. The actual lease area of the selected site was about 240.733 hectares. The location of mines and study area on the map is pointed and presented in Figure 2. The photographic view of the Malkapur mines pit-I is presented in Figure 3.

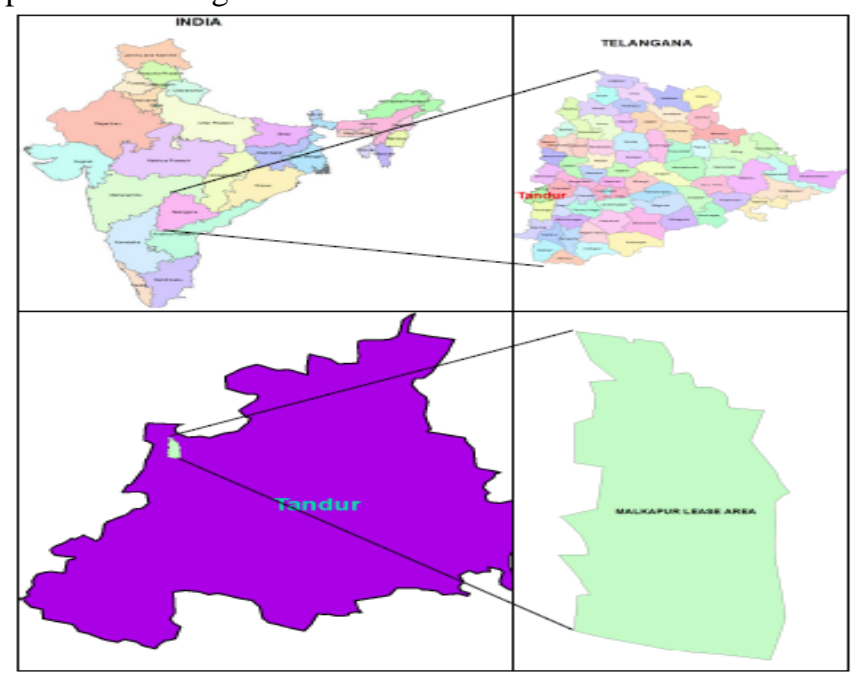

Fig. 2. Mapping of the selected site for the study

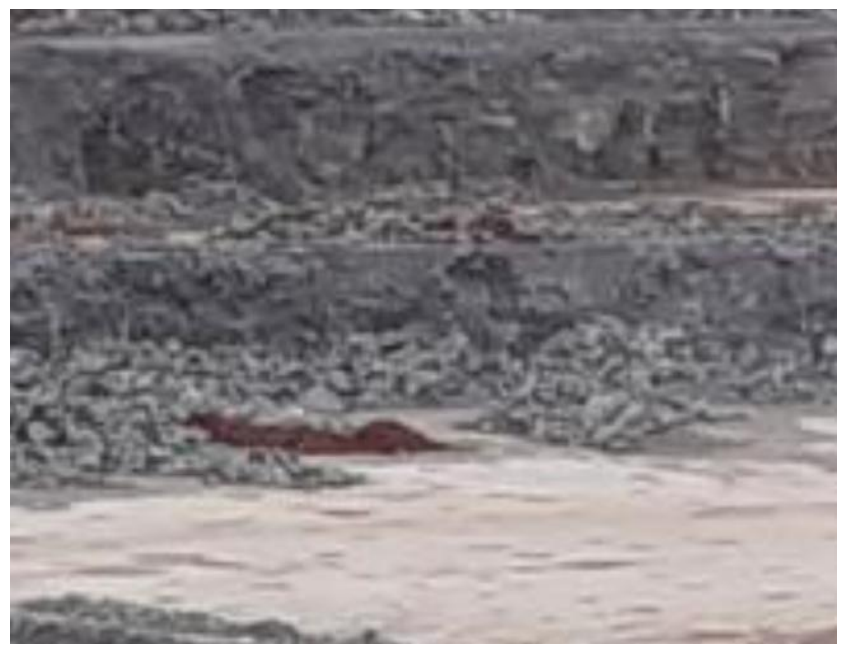

Fig. 3. Photographic view of pit-I

\section{METHODOLOGY-A FIELD STUDY}

The digital image processing techniques was used as prime techniques for this research work. The land Use and land cover features can be precisely captured by digital image processing techniques. The raw satellite data will be either downloaded or purchased, and is later stacked (process termed as "Layer Stacking"), followed by clipping (subset) the required area of interest using the buffer of 10 $\mathrm{km}$ boundary as input unit. The boundary of the buffer has been created around lease boundary of the mine area. The data is scaled to get a coloured enhanced image. The data is further rectified in ERDAS Imagine software to obtain a geo referenced satellite data. The data is first classified using Unsupervised classification technique to get an idea about the clusters of importance, which will enable the user to understand the range of DN (digital numbers). Simultaneously field work is completed to obtain GPS points of various land use classes and this is introduced as AOI (Area of interest) to classify the data using digital techniques. About 7 different land use and land cover classes in the study area were identified and classified as per the requirement. It is also possible to use a specific colour scheme to improve the appearance of the land use map. The system of land use and land cover classification is presented in Figure 4. The area of interest in the present research work and its two-level analysis is tabulated in Table 1. In Table I, sub section of the area of interest is drawn in two analysis form which is expressed as level-I and level-II.

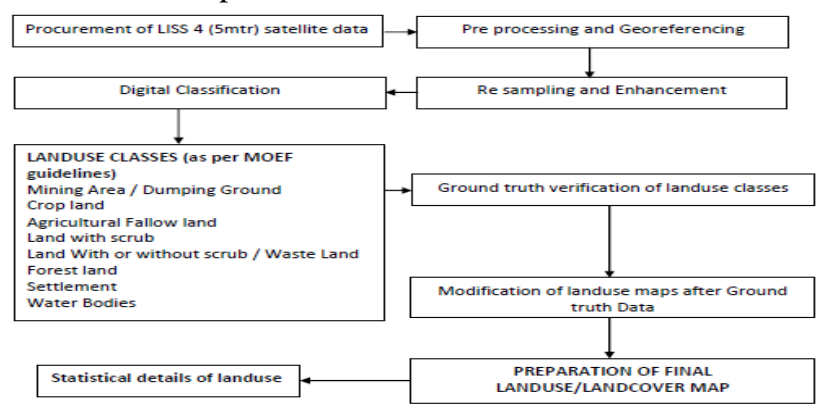

Fig. 4. Land use and land cover classification system 
Table -I: Area of interest and its two-level analysis

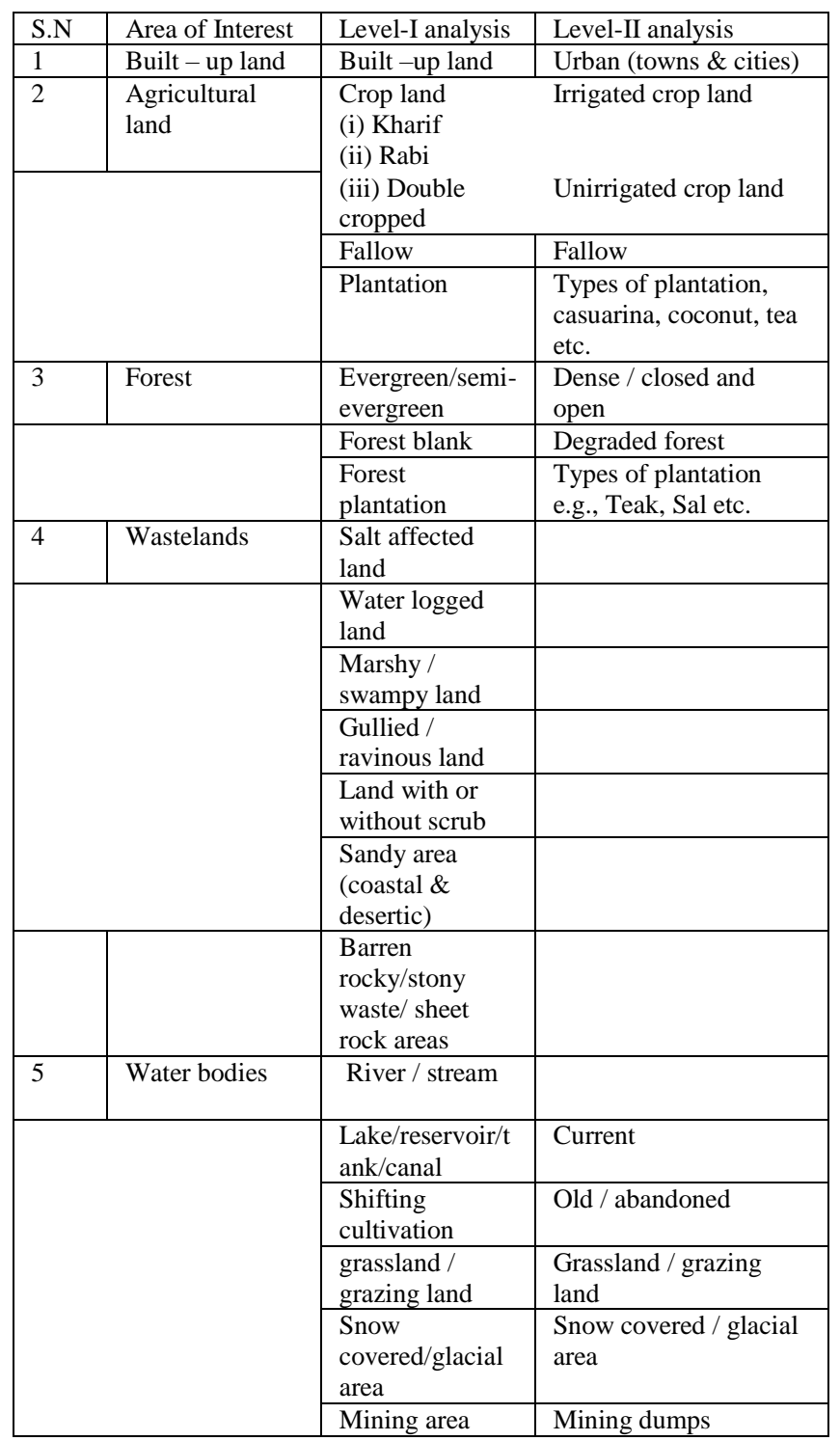

\section{RESULTS AND DISCUSSION}

The Ground truth verification of satellite data was conducted around the lease area to ascertain the land use classes as interpreted from satellite data as detailed below. These filed studies were conducted on the different various area of interest was performed in and around $10 \mathrm{~km}$ radius of the lease areas. The areas were surveyed at various intensity based on $1 \mathrm{~km}, 5 \mathrm{~km}$ and $10 \mathrm{~km}$ buffer with reduced no of field points. The details of field points and respective co-ordinates with field photograph is in Table 1 The data and images recorded for different area of interest as mentioned in Table-I, in this the photographic view of some of these areas are presented in Figure 5,6,7,8 and 9. These figures are presented with their respective recorded coordinates as mention in Figure 5,6,7,8 and 9. Figure 5 and 6 represents the irrigated land the harvested irrigated land. Similarly, Figure 7 and 8 are presenting the water bodies I and water bodies II respectively. Correspondingly, the Figure 9 depicts the observation of the forest area.

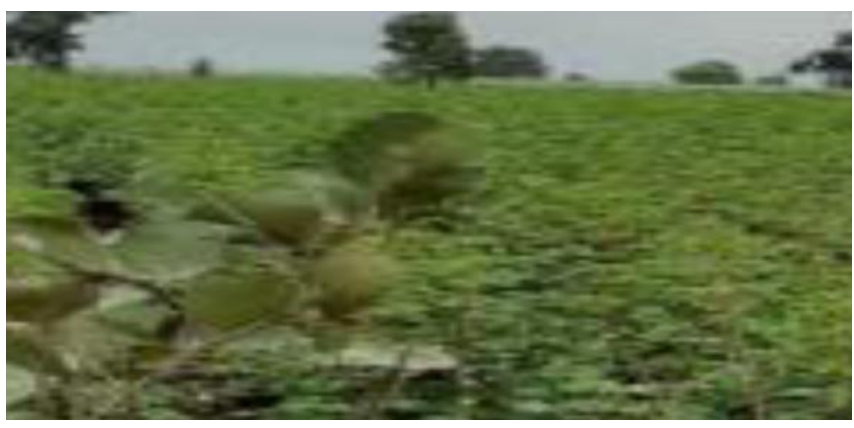

Fig. 5. View of irrigated land $17^{\circ} 38$ ' 80.56 '’ $N$,

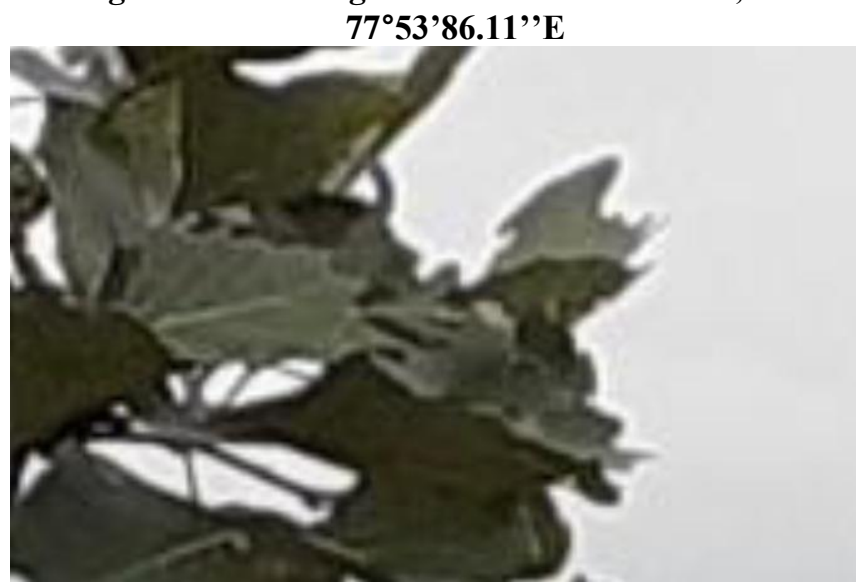

Fig. 6. View of irrigated land- Harvested $17^{\circ} 43^{\prime} 61.6$ ''N, $77^{\circ} 60^{\prime} 22^{\prime}$ ' E

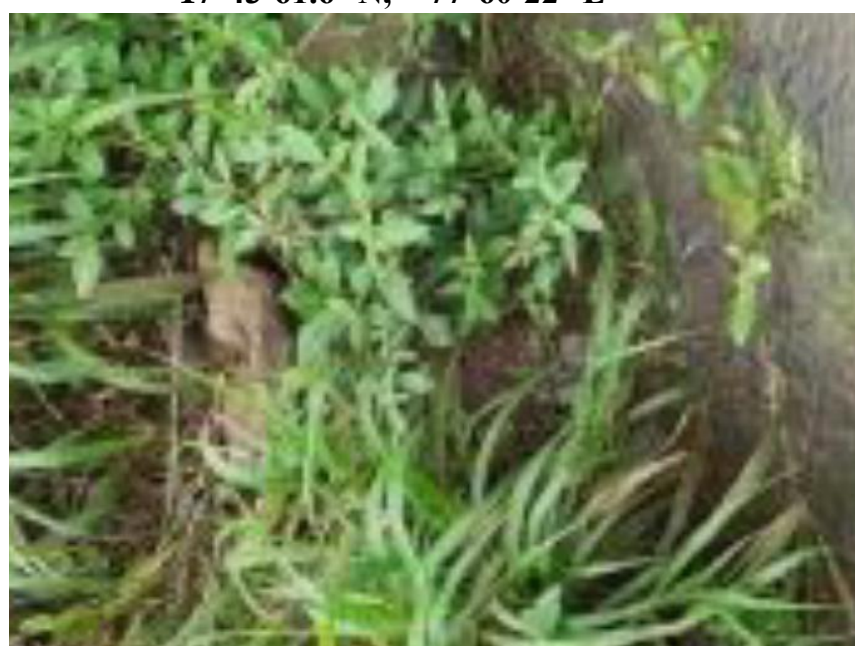

Fig. 7. View of water body-I $17^{\circ} 43$ ' 61 '’ $N$, $77^{\circ} 60$ '22''E

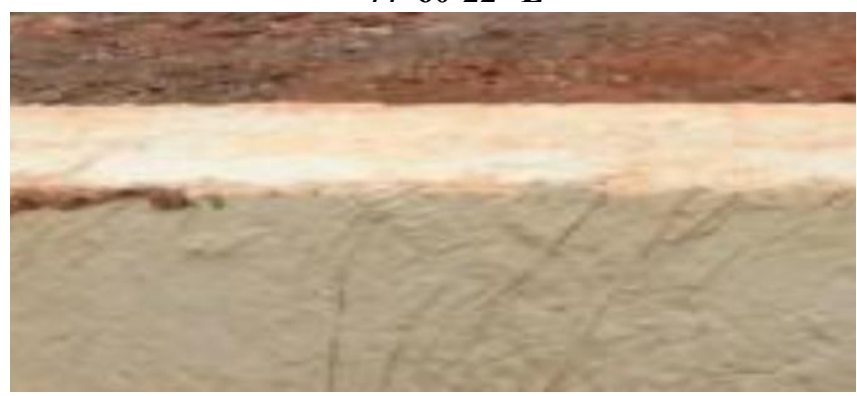

Fig. 8. View of water body-II $17^{\circ} 48^{\prime} 97.2$ '’ $\mathrm{N}$, $77^{\circ} 62{ }^{\prime} 47.2{ }^{\prime} \mathrm{E}$ 


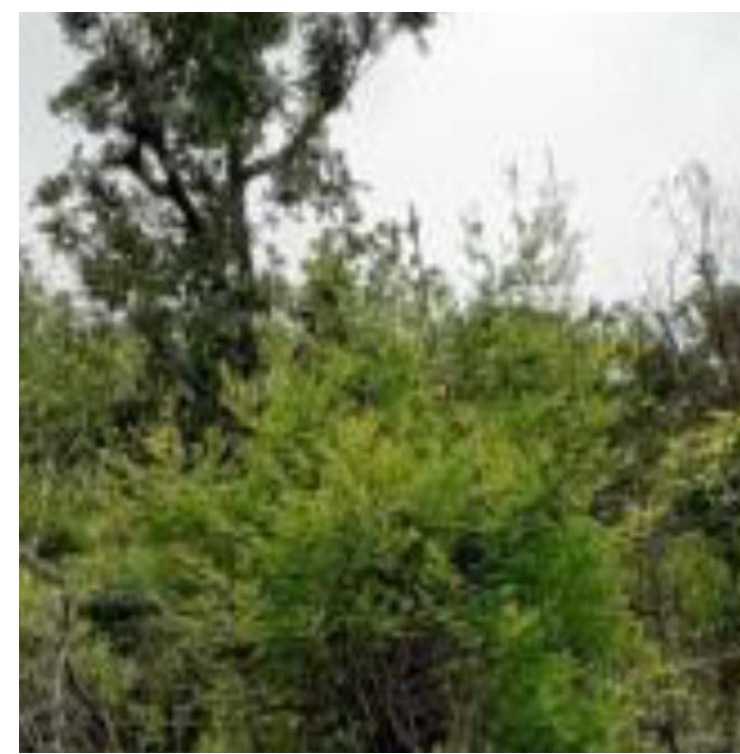

Fig. 9. View of forest area $17^{\circ} 49^{\prime} 69.4^{\prime} ' \mathrm{~N}, 7^{\circ} 51$ ' 66.66 '' $\mathrm{E}$

The analysis of any visible impact of current land use and land cover in and around mining areas was carried out in a very systematic manner. The majority of the area is coming under Irrigation, where most of the areas are irrigated for Rice crop , cotton and Pulses. The crops are cultivated in most of the areas in two seasons (kahrif and Rabi)/ Mine site is located at sufficient distance from these irrigated areas. Due to mine operations there is no impact to these irrigated areas or water bodies used for Irrigation. There are a few newly planted areas are visible in and around mining area as a requirement of Environmental balancing. The following tables II, III and IV shows current land use status. Further the obtained maps for the land used were presented in Figure 10, Figure 11 and Figure 12.

Table-II: Status of land use within $1 \mathrm{~km}$ buffer around the lease boundary using high resolution LISS IV data

\begin{tabular}{|c|l|l|}
\hline S. N & Class Name & Area (Ha) \\
\hline 1 & Mine & 50.5624 \\
\hline 2 & Land with Scrab & 279.2384 \\
\hline 3 & Land without Scrab & 32.1728 \\
\hline 4 & Plantation & 2.57512 \\
\hline 5 & Waterbody & 5.197543 \\
\hline 6 & Habitation & 42.1345 \\
\hline 7 & Irrigated Land & 871.4154 \\
\hline 8 & Total & 1283.29615 \\
\hline
\end{tabular}

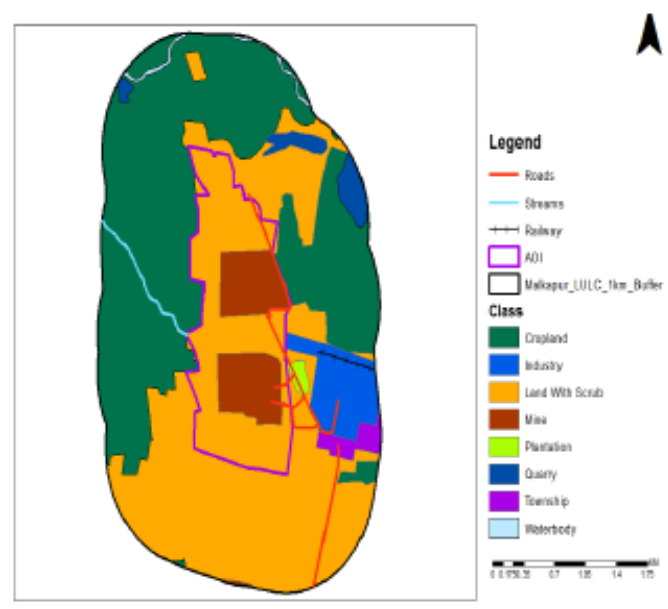

A

Fig. 10. Land use and land cover classification map of the mines for lease area of $1 \mathbf{~ k m}$

Table-III: Status of land use within $5 \mathrm{~km}$ buffer around the lease boundary using high resolution LISS

IV data

\begin{tabular}{|l|l|l|}
\hline S.N. & Class Name & Area (Ha) \\
\hline 1 & Mine & 1100.383013 \\
\hline 2 & Mining Dump & 7.202 \\
\hline 3 & Quarry & 145.1 \\
\hline 4 & Quarry Dump & 0.516 \\
\hline 5 & Hillock & 219.341 \\
\hline 6 & Scrub & 290.51 \\
\hline 7 & Land with Scrab & 68.561 \\
\hline 8 & Land without Scrab & 905.34 \\
\hline 9 & Plantation & 5.7512 \\
\hline 10 & Waterbody & 116.1536 \\
\hline 11 & Habitation & 603.2316 \\
\hline 12 & Irrigated Land & 8198.326618 \\
\hline & Total & $\mathbf{1 1 6 6 0 . 4 1 6 0 3}$ \\
\hline
\end{tabular}

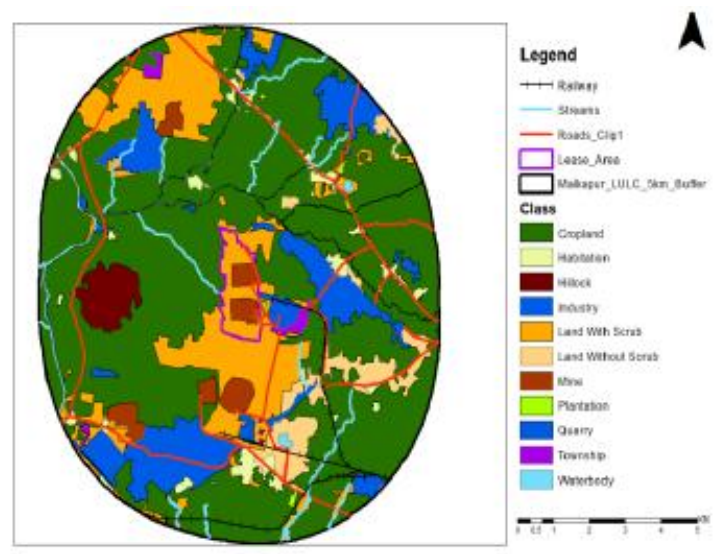

Fig. 11. Land use and land cover classification map of the mines for lease area of $5 \mathbf{~ k m}$

Table-IV: Status of land use within $10 \mathrm{~km}$ buffer around the lease boundary using high resolution LISS

IV data

\begin{tabular}{|l|l|l|}
\multicolumn{3}{|c|}{ IV data } \\
\hline S.N. & Class Name & Area (Ha) \\
\hline 1 & Mine & 1173.97558 \\
\hline 2 & Mining Dump & 7.202 \\
\hline 3 & Quarry & 415.50675 \\
\hline 4 & Quarry Dump & 0.516 \\
\hline 5 & Hillock & 219.341 \\
\hline 6 & Scrub & 571.56136 \\
\hline 7 & Land with Scrab & 506.3126 \\
\hline 8 & Land without Scrab & 2106.293012 \\
\hline 9 & Plantation & 81.6235 \\
\hline 10 & Waterbody & 537.275318 \\
\hline 11 & Water Logged & 14.51364 \\
\hline 12 & Habitation & 994.301629 \\
\hline 13 & Irrigated Land & 29937.8817 \\
\hline 14 & Forest & 2241.729438 \\
\hline & Total & $\mathbf{3 8 8 0 8 . 0 3 3 5 7}$ \\
\hline
\end{tabular}

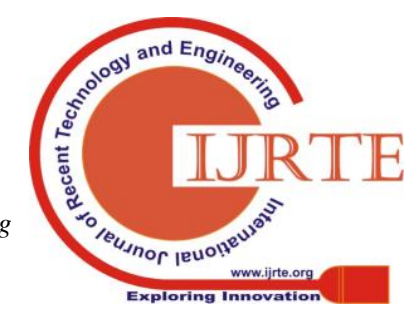




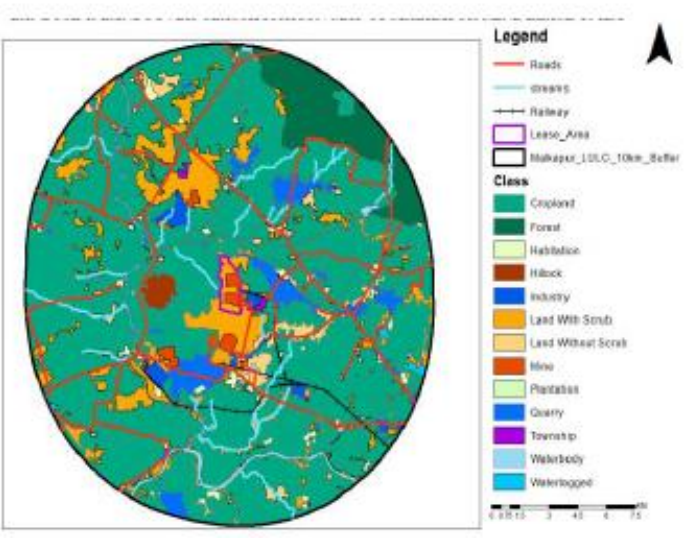

Fig. 12. Land use and land cover classification map of the mines for lease area of $\mathbf{1 0} \mathbf{~ k m}$

Fig. 12. Land use and land cover classification map of the mines for lease area of $10 \mathrm{kmThe}$ currently as per the mine plan the pit is being expanded in and around existing pits. The majority of expansion is in Pit 2 and pit 1 expansion is under progress. The expanded portion mostly fall under Waste lands of two land use types, land with scrubs and land without scrubs. The expansion is about $6.1 \%$ in Pit 2 and $2 \%$ in Pit 1 . However, in Pit 1 expansion is under progress. The following table give the details of current land use status. There is a minor change of $2.4 \%$ in habitation increase near mine site workers area and in the mine administrative area. However, there are a few habitation changes nearby villages due to normal village expansion factor.

As far as Agriculture is concerned there are not much of visible changes, however, a few areas due to individual farmers interest are keep as fallow and this leads to decrease in irrigated areas which is about $0.02 \%$. In water body also there is no visible change. In and around the mine site there are new plantations are grown has increased the planation area by $1 \%$. The change detection in and around of $1 \mathrm{~km}, 5$ $\mathrm{km}, 10 \mathrm{~km}$ buffer zones are presented in the Tables V, VI and VII.

Table-V: Observed changes in $1 \mathrm{~km}$ buffer zones

\begin{tabular}{|c|c|c|c|c|}
\hline $\begin{array}{l}\text { Class } \\
\text { Name }\end{array}$ & 2015 & 2019 & $\begin{array}{l}\text { Descriptio } \\
\text { ns }\end{array}$ & $\begin{array}{l}\% \\
\text { Varitation }\end{array}$ \\
\hline Mine & $\begin{array}{l}46.82910 \\
8\end{array}$ & $\begin{array}{l}50.562 \\
4\end{array}$ & $\begin{array}{l}\text { All around } \\
\text { the current } \\
\text { pits }\end{array}$ & 3.733292 \\
\hline $\begin{array}{l}\text { Land } \\
\text { with } \\
\text { Scrab }\end{array}$ & $\begin{array}{l}282.9840 \\
27\end{array}$ & $\begin{array}{l}279.23 \\
84\end{array}$ & $\begin{array}{l}\text { All around } \\
\text { the current } \\
\text { pits mainly } \\
\text { in Pit } 2\end{array}$ & -3.74563 \\
\hline $\begin{array}{l}\text { Land } \\
\text { without } \\
\text { Scrab }\end{array}$ & $\begin{array}{l}33.37382 \\
9\end{array}$ & $\begin{array}{l}32.172 \\
8\end{array}$ & $\begin{array}{l}\text { Mainly in } \\
\text { Pit } 2\end{array}$ & -1.20103 \\
\hline $\begin{array}{l}\text { Plantatio } \\
\mathrm{n}\end{array}$ & 2.515191 & $\begin{array}{l}2.5751 \\
2\end{array}$ & $\begin{array}{l}\text { A few } \\
\text { random } \\
\text { plantation } \\
\text { are } \\
\text { increased } \\
\text { towards } \\
\text { west }\end{array}$ & 0.059929 \\
\hline $\begin{array}{l}\text { Waterbo } \\
\text { dy }\end{array}$ & 5.237571 & $\begin{array}{l}5.1975 \\
43\end{array}$ & $\begin{array}{l}\text { Marginal } \\
\text { change due } \\
\text { to rainfall } \\
\text { variation }\end{array}$ & -0.04003 \\
\hline $\begin{array}{l}\text { Habitatio } \\
\mathrm{n}\end{array}$ & $\begin{array}{l}40.43566 \\
7\end{array}$ & $\begin{array}{l}42.134 \\
5\end{array}$ & $\begin{array}{l}\text { Increased } \\
\text { after } \\
\text { depleting a } \\
\text { few land } \\
\text { without } \\
\text { scrub areas }\end{array}$ & 1.698833 \\
\hline $\begin{array}{l}\text { Irrigated } \\
\text { Land }\end{array}$ & $\begin{array}{l}871.9207 \\
66\end{array}$ & $\begin{array}{l}871.41 \\
54\end{array}$ & $\begin{array}{l}\text { Marginal } \\
\text { changes } \\
\text { due to } \\
\text { permananet } \\
\text { fallow } \\
\text { lands }\end{array}$ & -0.50537 \\
\hline Total & $\begin{array}{l}1283.296 \\
159\end{array}$ & $\begin{array}{l}1283.2 \\
96159\end{array}$ & & \\
\hline
\end{tabular}

Table-VI: Observed changes in $5 \mathrm{~km}$ buffer zones

\begin{tabular}{|c|c|c|c|c|}
\hline Class Name & 2015 & 2019 & Descriptions & \%Variation \\
\hline Mine & 1078.806875 & 1100.383013 & All around the current pits & 21.57614 \\
\hline Mining Dump & 7.308735 & 7.202 & $\begin{array}{l}\text { All around the current pits mainly } \\
\text { in Pit } 2\end{array}$ & -0.10674 \\
\hline Quarry & 143.09398 & 145.1 & Mainly in Pit 2 & 2.00602 \\
\hline Quarry Dump & 0.302652 & 0.516 & $\begin{array}{l}\text { A few random plantation are } \\
\text { increased towards west and south }\end{array}$ & 0.213348 \\
\hline Hillock & 222.361283 & 219.341 & Not much of change & -3.02028 \\
\hline Scrub & 292.860341 & 290.51 & Decreased marginally & -2.35034 \\
\hline Land with Scrab & 67.965715 & 68.561 & $\begin{array}{l}\text { Marginal changes due to } \\
\text { permananet fallow lands }\end{array}$ & 0.595285 \\
\hline $\begin{array}{l}\text { Land without } \\
\text { Scrab }\end{array}$ & 932.577477 & 905.34 & $\begin{array}{l}\text { Decreased substantially upto } 2.5 \\
\text { \% due to mining activites }\end{array}$ & -27.2375 \\
\hline Plantation & 5.278468 & 5.7512 & Minor increase & 0.472732 \\
\hline Waterbody & 116.934668 & 116.1536 & No change & -0.78107 \\
\hline Habitation & 595.381872 & 603.2316 & $\begin{array}{l}\text { Increased by } 0.8 \% \text { due to } \\
\text { surrounding village habitations }\end{array}$ & 7.849728 \\
\hline Irrigated Land & 8197.543967 & 8198.326618 & No change & 0.782651 \\
\hline Total & 11660.41603 & 11660.41603 & & \\
\hline
\end{tabular}


Table-VI: Observed changes in $10 \mathrm{~km}$ buffer zones

\begin{tabular}{|c|c|c|c|c|}
\hline Class Name & 2015 & 2019 & Descriptions & $\begin{array}{l}\% \\
\text { Variation }\end{array}$ \\
\hline Mine & 1150.956454 & 1173.97558 & All around the current pits & 23.01913 \\
\hline Mining Dump & 7.308735 & 7.202 & $\begin{array}{l}\text { All around the current pits mainly in } \\
\text { Pit } 2\end{array}$ & -0.10674 \\
\hline Quarry & 410.403475 & 415.50675 & Mainly in Pit 2 & 5.103275 \\
\hline Quarry Dump & 0.302652 & 0.516 & $\begin{array}{l}\text { A few random plantation are increased } \\
\text { towards west and south }\end{array}$ & 0.213348 \\
\hline Hillock & 222.361283 & 219.341 & Not much of change & -3.02028 \\
\hline Scrub & 583.762477 & 571.56136 & Decreased marginally & -12.2011 \\
\hline Land with Scrab & 521.503252 & 506.3126 & $\begin{array}{l}\text { Marginal changes due to permanent } \\
\text { fallow lands }\end{array}$ & -15.1907 \\
\hline Land without Scrab & 2122.293068 & 2106.293012 & $\begin{array}{l}\text { Decreased substantially upto } 1.5 \% \\
\text { due to mining activities }\end{array}$ & -16.0001 \\
\hline Plantation & 77.53437 & 81.6235 & $\begin{array}{l}\text { Increase by } 2 \% \text { due to mine } \\
\text { environmental activities }\end{array}$ & 4.08913 \\
\hline Waterbody & 543.475358 & 537.275318 & No change & -6.20004 \\
\hline Water Logged & 12.312275 & 14.51364 & Small change not a big impact & 2.201365 \\
\hline Habitation & 987.411629 & 994.301629 & $\begin{array}{l}\text { Increased by } 0.8 \% \text { due to surrounding } \\
\text { village habitations }\end{array}$ & 6.89 \\
\hline Irrigated Land & 29935.6791 & 29937.8817 & No change & 2.2026 \\
\hline Forest & 2232.729438 & 2241.729438 & Increased by $1 \%$ & 9 \\
\hline Total & 38808.03357 & 38808.03357 & & \\
\hline
\end{tabular}

From the above tabulated tables, it can be seen that there is no there is no impact of any change in land use due to the mining activities during the year 2019. Among all the area of interests mainly irrigated lands are not having any visible changes which can be attributed to land use change. Further, it can be observed that there is good amount of development in around the pit as part of mine development and mine expansion as per mine planning. Also, the water bodies are intact and not much changes are visible. Moreover, it was observed that there was slight change in irrigated lands where a few agricultural lands are converted into Permanent fallows and a few areas are reclaimed into Agricultural lands. However, the acreage is not changed (around 2\% decrease). This is mainly due to individual farmers decision. It was also observed that the mining company has done additional plantation as a part of environmental activities.

\section{CONCLUSIONS}

Now a days the analysis of land use and land cover in and around the mines is becoming a very essential activities in the recent years. In this paper, the digital image processing was used for analysis the land use and land cover areas. The used digital image processing methods was purely based on the passive remote sensing techniques. In this paper, the changes occurred in and around mines was observed for the buffer radius of $1 \mathrm{~km}, 5 \mathrm{~km}$ and $10 \mathrm{~km}$. This study clearly reveals that there was not much of changes in land use which intern implies that mining activities are not having any impact in land use changes. Similarly, there was no visible changes observed in the water bodies of the surrounding mines areas. However, there was a slight decrease in the acreage of $2 \%$ was reported which was mainly due to the individual farmers decision. Further, the good number of green plantations was observed which were planted by the mining company as the part of the environmental activities.

\section{REFERENCES}

1. A.K. Banerji, "On the Precambrian banded iron-formations and the manganese ores or the Singhbhum region, eastern India," Economic Geology, 1977, 72(1), pp. 90-98.

2. K. K. Chandan, V.A. Jha, K. Sairaj, S.A. Singh, and A.S. Venkatesh, "Greenfield exploration prospects of orogenic gold mineralization in and around Lawa Area, North Singhbhum Mobile Belt, Eastern Indian Craton,” Int. J. Appl. Nat. Sci, 2013,2, pp. 81-90.

3. S. Acharya, G.C. Amstutz, and S.K. Sarangi, "Diagenetic crystallisation and migration in the banded iron formations of Orissa, India," In Ore Genesis, Springer, Berlin, Heidelberg, 1982, pp. 442 450 .

4. W. Wagner, D. Sabel, M. Doubkova, A. Bartsch, and C. Pathe, "The potential of Sentinel-1 for monitoring soil moisture with a high spatial resolution at global scale," In Symposium of Earth Observation and Water Cycle Science, 2009.

5. J. Li, J. Fang, Z. Lu and L. Bai, "Airborne position and orientation system for aerial remote sensing" International Journal of Aerospace Engineering, 2017.

6. M.E. Miller, W.J. Elliot, M. Billmire, P.R. Robichaud, and K.A Endsley, "Rapid-response tools and datasets for post-fire remediation: linking remote sensing and process-based hydrological models,' International Journal of Wildland Fire, 2016, 25 (10), pp.1061-1073.

7. A. Porwal, and E.J. Carranza, "Introduction to the Special Issue: GISbased mineral potential modelling and geological data analyses for mineral exploration" 2015.

8. E.J.M. Carranza, "Geocomputation of mineral exploration targets," Computers \& Geosciences, 2011, 37(12), 1907-1916.

9. R.A. Schowengerdt, "Techniques for image processing and classifications in remote sensing" 2012, Academic Press.

10. J.J. Lee, and M. Shinozuka, A vision-based system for remote sensing of bridge displacement, Ndt \& E International, 2006, 39(5), 425-431.

\section{AUTHORS PROFILE}

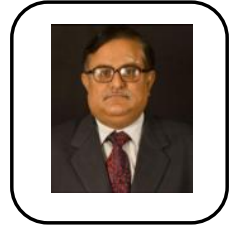

countries.
Dr K. S. Siva Subramanian Prof and head mining engineering department AMET University did doctorate in mineral exploration from IIT Mumbai. Has worked as Sr Vice President at MNC RMSI Pvt Ltd -Natural Resources business unit. He has 30 years of mining and mineral industry experience. He published 25 papers in international magazines and executed projects in 25 


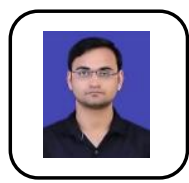

Dr. Abhishek Kumar Tripathi received his degree in Mining Engineering in the year 2014 from National Institute of Technology Rourkela, India. He earned his Ph.D. degree from National Institute of Technology Karnataka, Surathkal in the year of 2019. He has published 34 research articles in reputed journals and conferences. He is also a member of several professional bodies. He awarded as a Best Research Paper Award in 2nd International Conference on Paradigm in Engineering \& Technology (ICPET-2018) during 28th and 29th December 2018. He recognized and honored as a Fellow of Engineering Research Council (FERC) by Global Journals, a society Accredited ISO Certified and United State Corporation Under Open Association of Research Society (USA). Recently, he awarded as the excellent researcher award by International Academic and Research Excellence Award 2019 in association with GISR foundation Team. Currently, he is working as an Senior Assistant Professor in Aditya Engineering College (Autonomous), Surampalem, Andhra Pradesh, India. His research interests include Rock Mechanics, Renewable Energy Sources, Mines Power System, Mine Environment.

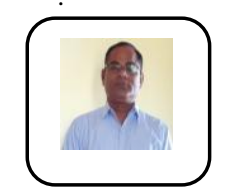

Mr. Ramesh Kant is working as a Faculty in Mining Engineering Department AMET University, Chennai. He has the 5 Years teaching experience. He also has the 8 years working experience in coal and metal mines Industry. He published 4 International Peer Reviewed Blasting Engineering. Paper. Currently, he is doing his research in the area of 